\title{
Women in the Brotherhood: Gender, Class, and Politics in Renaissance Bolognese Confraternities
}

\author{
NICHOLAS TERPSTRA
}

M ona Lucia Bolza and her spiritual sisters had a bone to pick with the men of Bologna. For decades women had been progressively shut out of worshipping in lay confraternities. Now, in 1547, they made a stand. A group of perhaps thirty gathered at the shrine of S. Maria delia Pietà on the eastern wall of the city before the men of the shrine's confraternity met for evening prayers. With Mona Lucia doing the talking, they demanded, first of God and then of the confraternity officials and men, permission to join in the gatherings under the mantle of the Virgin Mary. The women wanted to congregate in the shrine to the service, honour, and glory of God, and they wanted to be subject to all that the confraternal statutes and oath required of the men. The men received all of this in their hearts and, in a secret vote, unanimously approved the women's demands. The women then asked the men to give them a head and guide-so long as it was not one of their husbands. In prayer, and by the will of God, they elected and confirmed Mona Lucia as Prioress for the coming year.

This Authorized Version of the sisters' successful assault on a bastion of male privilege occurs in the prologue to the statutes drawn up for the women of S. Maria della Pietà in the following year. ${ }^{1}$ The triumphal tone does not quite obscure the signs of advanced planning evident in the ritualized assault, nor can it obscure the result that becomes clearer in the statutes themselves. The women did not join the men under the mantle of Mary, under the statutes and oath, or, for that matter, in the shrine. ${ }^{2}$ Their consorority was separated from, but administered by, the men's confraternity; their devotional exercises excluded the offices and flagellation characteristic of the men's devotion; and they were not given any reason to meet in the shrine's oratory. Even their statutes appear to have been written in part by the men. ${ }^{3}$ Why then was the ritual confrontation staged, and why was the women's defeat portrayed as a 


\section{4 / Renaissance and Reformation}

victory? Why were the women not granted what they wished? Gender, class, and politics mixed in a confrontation which brought to a head developments originating a century earlier. Two views of women's religious role interacted in the confrontation: The first was the goal of an active apostolate of charity and public worship which had been common among artisan confraternities until devotional reforms of the mid-Quattrocento. The second was the ideal of a contemplative discipleship of private prayer and devotion that was common among high-born confraternities. Women's removal from Bolognese confraternities had come as a result of devotional reforms pursued through the later Quattrocento by men who were largely of their own artisan class. Their re-entry in the next century was a calculated move by patricians concerned less with religious expression than social control. Only a public ritual would achieve the political purpose, but fixed patrician notions of the religious expression appropriate for women would ensure that their aggressive demands could not be granted.

The study of organized lay piety is the study of confraternities. Italian lay men and women began gathering in confraternities in the thirteenth century, often after having experienced the intense and exciting public worship of periodic devotional movements. ${ }^{4}$ In Bologna as elsewhere in Italy, a penitential movement of 1260 , marked by processions and public flagellation, was perpetuated by lay worshippers meeting regularly for prayers and singing. ${ }^{5}$ Drawing on the models of mendicant orders and artisanal guilds, they devised statutes that regulated individual and collective devotions and established administrations empowered to acquire material and spiritual goods. Within a few decades, more groups were following the example of the penitents of 1260 , building oratories and buying indulgences while meeting in regular worship. The number of Bolognese confraternities grew in waves, with peaks in the first decades of the fourteenth, fifteenth, and sixteenth centuries. Two great reform movements in the mid-fifteenth and early-sixteenth centuries stirred up existing groups gone stale, but reforms almost never entailed schismatic break-ups. Reformers were accommodated in a sub-group of the confraternity, named the stretta company, with the term doing double duty to indicate narrow membership and strict devotional activities similar to the northern Devotio Moderna and mendicant Observant movements. ${ }^{6}$ The remaining brothers who had not joined the reformers were called the larga company. By the mid-sixteenth century, over eighty confraternities and stretta sub-groups were or had been active in the city of $50,000 .{ }^{7}$ Of these, twelve definitely enrolled women. ${ }^{8}$ 
Women's early involvement in organized lay piety in Bologna was determined by the circumstances and models shaping confraternal development. Born of public devotional movements, confraternities could not exclude from their worship the women who had sung and prayed in procession. Yet governed on the model of artisanal guilds, they would not include in their councils a sex that played no administrative part in the guilds. The mendicant model was ambivalent. On one hand it advocated a life of piety expressed through public charity. On the other, it gave the example, from St. Clare onwards, that women in Second Order mendicant houses could only practise their piety and charity within the boundaries of strict enclosure. As two types of confraternities emerged through the Trecento, women's participation fell into two tracks that were commonly, if not exclusively, distinguished by social class. Laudesi, or praising confraternities, picked up on the celebratory and communal side of devotional movements. These were large, neighborhood-based groups gathering men and women of the artisan class. They usually met monthly in a mendicant church to sing and pray in public worship. Beginning in the early fourteenth century, the laudesi confraternities established ospedali, or hostels, which served the thousands of pilgrims who passed through Bologna each year. While laudesi groups perpetuated the public and celebratory side of devotional movements, battuti or flagellant confraternities carried on the penitential and individualized element. Based more self-consciously on the mendicant model, they were smaller and more socially exclusive in choosing members. In place of the public worship of the laudesi, they gathered weekly in private oratories to recite the Divine Office. On feast days and during Lent and Advent, they flagellated in the darkened oratories. Bolognese battuti did not establish charitable works like the laudesi hostels until later in the fourteenth century, when they began treating the sick and dying of the city itself.

Women initially joined laudesi confraternities and played an important part in the charitable work of their hostels, but were normally excluded from the flagellant battuti groups. Their exclusion was ostensibly to avoid exacerbating the public scandal that already attended a nocturnal activity carried out in darkened oratories by semi-naked participants. Peter Damian had first advocated flagellation as a penitential exercise for laity of all social conditions in the eleventh century, and Franciscan preachers further popularized the practice from the thirteenth century. Italian women certainly flagellated from at least the eleventh century, but did so in private and risked incurring disapproval. ${ }^{9}$ The sticking point was not flagellation per se, but its collective practice in processions or confraternities. None of the chronicles documenting 
the 1260 movement of Disciplinati mention women flagellating in streets or churches, and only one refers to women performing the exercise "in cubiculis suis . . cum omni honestate." 10 While the women of Ravenna were the first to win entry into a flagellant confraternity in 1265 , it is doubtful that they gained anything more than the spiritual benefits of auxiliary association. This was certainly the case with women admitted into flagellant confraternities in contemporary Vicenza, Bergamo, Pisa, Udine, Modena, Cividale, and San Sepolcro. ${ }^{11}$ As the wives and daughters of male members, they were of higher social standing than the women joining laudesi confraternities.

Women's exclusion from the collective flagellation characteristic of battuti groups was based on more than just the shame of exposing their bodies or mixing male and female flagellants, since it continued through the period when those bearing the cords wore robes and hoods which obliterated their individual identity. More importantly, even the few "flagellant" consororities in thirteenth- and fourteenth-century Italy may not have practised the exercise. Contemporaries referred to the women of the late-Trecento Company of S. Maria di Giosafat in the Sicilian town of Catania as "domne disciplinantes," but this appears to have been little more than a convention following the model of male confraternities from which women were excluded. ${ }^{12}$ The consistency and completeness of the exclusion suggests that collective flagellation was seen as a distinctly male ritual, the characteristic expression of the generally more patriarchal mores of the battuti groups. ${ }^{13}$ Given these values, it is doubtful that women played any more than an auxiliary role in any flagellant confraternities anywhere in Italy during this period. ${ }^{14}$ Just as the flagellant confratello's collective devotions and charity were lay reflections of the mendicant rules, so the consorella's private devotions and limited activities reflected the strict enclosure of female religious.

Members of both laudesi and battuti confraternities oriented their worship to death, dying, and salvation. As Brian Pullan noted of the Venetian confraternities or scuole,

[they] existed to prepare for death and to maintain a bond with the dead: to commemorate them and, through the celebration of Mass for the souls of the living and of the dead, to speed their passage through Purgatory. The founders of the Scuole set themselves to do, as a congregation or a fraternity, things which contributed to the salvation of the soul, to correct sin, to make peace, and to accumulate a fund of merit on which all could draw. ${ }^{15}$ 
Women contributed equally to this fund of merit with their prayers, worship, regular dues, and charitable works. Their charity was particularly evident in laudesi confraternities operating hostels; fifteenth-century female members of S. Bartolomeo di Reno frequently clothed the poor clerics served by their hostel. ${ }^{16}$ Moreover, through the fourteenth and early fifteenth-century Bolognese women of artisan rank often outdid men in joining laudesi confraternities. Yet their involvement sharply declined from the latter half of the fifteenth century. To take one example: the Company of S. Maria dei Guarini, an artisanal laudesi group centred in the south-eastern quarter of Porta Piera, registered seventy men and seventy women in a matriculation list begun in 1356. By 1382 the female complement had risen to 181 and the male to 172 . A 1428 revision showed at least 120 women and 128 men. ${ }^{17}$ At this point the rough equality disappeared. The 1428 matriculation list extended to 1526 , registering a total of 627 men and 239 women; women's recruitment had dropped to less than twenty-five percent, and was being gradually eliminated altogether; neither the larga nor the stretta matriculations commencing in 1526 listed women as members. A similar process was underway in the laudesi Company of S. Maria della Carità centred on the south-western quarter of Porta Stiera. This group had been winding down in the latter fourteenth century, but revived itself in the aftermath of the 1399 Bianchi devotional movement. The 1399 matriculation list showed fifty-two women and thirty-one men; over the life of the list into the 1530s, the proportions were reversed, with a total of 300 men to 219 women. The figures are deceptive. Most of the men went over to the stretta group formed in 1518, and by the 1530s the larga group was on the verge of collapse. Appendix A charts male and female recruitment for a number of Renaissance Bolognese confraternities, and shows how with one exception the proportion of women declined through this period.

Recruitment was seriously dropping, but this was still only half the issue. How many of the women joining a confraternity drew on its fund of merit? Only those who were active members at the time of death could, so to speak, draw on the fund. Their bodies were dressed in the confraternity's robes and buried in its sepulchre, while their souls were propelled quickly through Purgatory by the prayers, requiems, and plenary indulgences of their spiritual community. In the event, few women lasted this far. Most confraternities had greater difficulty retaining female than male members. Of the 248 members participating in the Company of S. Maria dei Guarini in 1428, ninety percent of males remained active until death, but only eight percent of females. Over the remainder of the matriculation list male participation till death dropped 
to twenty-six percent, while women's rose to fourteen percent. ${ }^{18}$ The female dominated S. Maria della Carità group of 1399 retained ninety-six percent of women until death, but in subsequent generations this dropped to fifty-five percent. And while retention rates varied widely among confraternities, Appendix B shows that those for women were usually about half of those for men.

Declining recruitment and retention rates for women were the consequence both of their exclusion from the administrative responsibilities of male membership, and of the growing predominance of the flagellant model in confraternal devotional reform. Ronald Weissman has shown that administrative responsibility was a condition for men continuing their membership in contemporary Florentine confraternities; without powers to exercise and duties to perform, members simply lost interest and dropped away. ${ }^{19}$ If women were accustomed to this kind of discrimination in artisanal society, they were less prepared for a redefinition of confraternal worship which would exclude them as a matter of principle. This is precisely what was happening from the mid-fifteenth century, when the Observant reforms dividing the major mendicant orders spilled over to influence lay confraternities. Male reformers who established stretta sub-groups in laudesi confraternities emphasized the danger or pericolosità of Woman, an evil sex that led men away from devotion and into temptation. There was nothing particularly new in this revival of misogynistic and patriarchal themes in popular piety. Yet by making flagellation the characteristic mark of stretta renewal, reformers excluded women from the most dynamic and fastest-growing segment of the confraternity.

In its confraternal context, flagellation was less an act of individual purification or expiation, than a demonstration of love and solidarity with Christ. Confratelli frequently adopted conventions or rituals of imitative piety that cast them as the disciples and their lay head [the Ordinario] as Christ. Companies ascribed their origin to the actions of twelve men, or assigned revision of their statutes to a committee of twelve members. The Holy Thursday festival, which was one of the most solemn collective feasts, included a ritual in which the Ordinario washed the feet of all members or of a group of twelve; we also find flagellation limited to groups of twelve. While these numerical conventions were no doubt welcomed by squeamish or high-born members who wished to avoid potentially painful or demeaning exercises, they originated in the effort to underline the group's collective identity as friends, disciples, and imitators of the Signore. ${ }^{20}$ The flagellants shared in the suffering of the Head and Groom of the Church, giving collective 
discipline its strongly male meaning. ${ }^{21}$ Bolognese battuti began abandonning the exercise by the late Trecento, but its link to confraternal renewal was re-affirmed by Bishop Nicolò Albergati [1375-1443], a Carthusian Observant from a prominent local family. As part of a broad-ranging program to revive the spiritual life of the city, Albergati reformed some of the city's patrician confraternities in the first half of the fifteenth century, creating flagellant stretta cells to restore their inner life and giving them larger roles in public religious ceremonies. ${ }^{22}$ Artisanal laudesi groups that reformed themselves according to the Observant model over the next seventy-five years began picking up the cords of discipline as well. In the process, these laudesi stretta groups also adopted the secrecy and membership restrictions of the patrician battuti; all strangers, and particularly women, were excluded from the confraternal oratory.

Once a stretta sub-group was erected within a laudesi confraternity, the larga parent usually lost its devotional purpose and members. The larga of S. Maria della Carità, which lost forty-two of its members to the stretta in 1518 , was extinct by 1542 ; the stretta specifically prohibited creating another in its 1577 statutes. ${ }^{23} \mathrm{~S}$. Bartolomeo di Reno's larga company waned so quickly after the stretta emerged in 1502 that members joining a few decades later were unaware it had ever existed. ${ }^{24}$ In S. Maria dei Guarini, the larga group was reduced to a Board of Governors for the hostel. In none of these cases was any provision made for continuing the public worship once characteristic of the laudesi. As a result, Observant reforms shut lay women out of participating in either the devotional or the charitable activities of the confraternity. ${ }^{25}$ Two groups continued admitting women. The patrician flagellants of S. Maria del Baraccano added small numbers of female relatives as auxilliary members. The laudesi of S. Bernardino, who met in the Conventual church of S. Francesco and never split into stretta and larga groups, also recruited women; this was the only major laudesi confraternity to resist the Observant reforms, and the only one to see its proportion of female members rise through the sixteenth century.

The Observant model, with its emphasis on a life of private contemplative devotions for women, dominated late fifteenth- and early sixteenth-century Bologna. Women's enthusiasm for the strict Observant life can be seen in the number of recruits garnered by reformed convents, and in the enormous popularity of two female spiritual leaders. In 1425, Bishop Albergati put the Augustinian nuns of S. Maria delle Virgini under a strict rule, and in seven years their numbers quadrupled from six to twenty-four, doubling again over the next four decades. Other mendicant orders imposed Observant rules on 
their Bolognese Second Order houses as well, notably the Cistercians [1429], the Camaldolese [1433] and the Franciscans [1436]. ${ }^{26}$ In 1432 the Franciscan tertiary Caterina di Vigri [1413-1463] established a convent of Poor Clares in Ferrara in order to follow a strictly-enclosed life. After relocating the convent to her birthplace of Bologna in 1456, she gained the patronage of the Bentivoglio and won such a reputation for sanctity that local followers founded a popular cult and pushed successfully for her beatification in $1524 .^{27}$ All of the reformed convents won steadily increasing numbers of recruits. Some of this growth was undoubtedly a parental response to demographic and dowry pressures, but women's own participation in Observant values is confirmed by the wide lay following won in the early Cinquecento by Elena Duglio dall'Olio [1472-1520]. Though married to a Bolognese notary, Elena followed and championed a life of chastity and contemplative devotion, and became a cult figure even before her death. Her followers emphasized her similarity to the Madonna, while Raphael was commissioned to depict her as an otherworldly St. Cecilia in the altarpiece for her chapel in the Lateran Canons' church of S. Giovanni in Monte. ${ }^{28}$

In most cases lay artisanal women of the late fifteenth and early sixteenth century were being shut out of laudesi confraternities by the desire of male reformers to follow the Observant mendicant model. Yet ironically, these artisanal men were themselves soon marginalized in their brotherhoods. In this case, the political changes affecting Bologna in the latter years of the Bentivoglio signory and the early years of papal governorship provided the motive force. Bequests left to the older confraternities, particularly those operating hostels, had grown to the point where some were quite wealthy. Through the fifteenth century, laudesi ospedali had become more specialized and localized in their work, gradually turning themselves from hostels for pilgrims passing through Bologna, into orphanages and infirmaries for the worthy poor of the city itself. Civil and ecclesiastical authorities had encouraged unions among these institutions in order to improve co-ordination and control of social relief. New companies arose, such as S. Maria degli Angeli which ran a foundling home modelled after Florence's Ospedale degli Innocenti. The final fall of the ruling Bentivoglio family in 1512 set the stage for the creation of a broader Bolognese oligarchy intent on preserving a high degree of magnate latitude under the newly-confirmed papal rule. As one step in the consolidation of their power, the leading families moved systematically to take firmer control of the confraternities and their ospedali. ${ }^{29}$ The Company of S. Maria dei Guarini provides the clearest example, with its creation in 1525 of a self-perpetuating board of ten sindics appointed to life terms to 
administer its infirmary for syphilitics. Beginning with a bare majority, the patrician group progressively increased its numbers on the board, adding even those who were not members of the confraternity. Most artisan members had joined the confraternity's newly-formed stretta group in 1518 and soon they complained that they were being excluded from the infirmary's board while high-born strangers were being admitted. Their protests fell on deaf ears. The patricians argued that they had been appointed by the larga and not the stretta, and so had no obligations towards the latter. Since the former was defunct within a decade, this gave them a free hand. Angry at the theft of a charitable institution that their ancestors had founded two hundred years earlier, the stretta artisans tried various avenues of protest before successfully bringing a suit to the episcopal court. The patricians initially refused to acknowledge the judgement, but finally tired of the artisans' relentless pursuit of their cause. In 1602 they offered the olive branch of an ex officio seat on the infirmary board, thereby winning peace without sacrificing control. ${ }^{30}$

The Bentivoglio themselves had demonstrated the techniques and effectiveness of winning control over confraternal social agencies at the foundling home of S. Maria degli Angeli in the late-fifteenth century. Their successors followed the example at the orphanage of S. Bartolomeo di Reno and other ospedali through the next decades. In the process they gained valuable expertise for a local welfare system adopted in the 1540s and 1550s, and based loosely on Juan Luis Vives De subventione pauperum [1526]. ${ }^{31}$ Artisan confratelli seldom resisted the patrician takeover as tenaciously as the men of S. Maria dei Guarini; indeed, many initially welcomed high-born members whose deeper pockets would fund faltering ospedali. Few anticipated their own inevitable disenfranchisement. Yet all confraternal matriculation lists from the early sixteenth century onward show a growing number of prominent families, and decreasing artisanal membership in the Bolognese spiritual companies; a similar process was underway in Grand Ducal Florence. ${ }^{32}$ Hence, while women were pushed out of artisanal confraternities as a result of patriarchal devotional reforms adopted in the fifteenth century, artisanal men were themselves marginalized within their confraternities by political developments of the following century that re-inforced a hierarchical social order.

Given these developments, what was at work in Mona Lucia's 1547 appeal to the men of S. Maria della Pietà? The confraternity was impeccably upper class; all the legitimate males of the Bentivoglio family had joined it soon after it began in 1503.33 The Bentivoglio's fall did little to hinder its ability to gather such leading families as the Gozzadini, the Bianchi, the Dolfi, and 
others. Mona Lucia's husband, Guaspar, was also a member. The prologue to the consorority's 1548 statutes implies that Bolognese women strongly resented their marginalization in the confraternities, to the point perhaps where the oligarchy felt it advisable to contain the dissent. Yet while the dissenting women sought an active apostolate and full involvement in confraternal life, the only response Bologna's patricians seemed capable of offering was the contemplative devotional life of the Observants. The ritual assault by the stalking horse Mona Lucia symbolically put "women on top," while the statutes that followed firmly put women in place as the 'enclosed' spiritual auxiliaries of the confraternity. ${ }^{34}$ Apart from monthly confession and quarterly communion, the repeated Paters and Aves that made up their devotions were to be said at home. The statutes allowed for monthly meetings, but specifically prohibited the women from saying Divine Office, and are silent on what other duties they might perform or business they might transact. ${ }^{35}$ Unlike their sisters in Roman confraternities, the women did not join in confraternal processions, anniversary requiems, or feasts. ${ }^{36}$ In administration, the relative autonomy modelled by stretta groups was not granted to the women, even though S. Maria della Pietà had itself operated with a stretta group since at least 1537. ${ }^{37}$ The men's Ordinario and Prior supervised the women's annual election of a Prioress, and this woman was then put under the headship of a male Governor elected by the women but confirmed by a capitular vote of the men's company. ${ }^{38}$ The Prioress was to be an honest and reputable married woman over twenty-five years old; she was assisted by two female counsellors who had no specific duties. All financial affairs and relations with the men's confraternity were handled by the Governor, who presented annual audits to his companions; after 1600 he was appointed directly by the men's company. ${ }^{39}$ The recurring theme in the women's statutes was obedience: in the company, in the church, and in the body politic. Obedience to the Prioress and Governor was likened to the obedience due from Lords to the Emperor, from the French to their King, from ecclesiastics to the Pope. "Without obedience, our republic of Bologna would be full of atrocities and assassinations." 40 As, indeed, it usually was.

Obedience to husbands and fathers is conspicuously lacking from the 1548 statutes: the models are all politically hierarchical rather than familially patriarchal. The women themselves underlined this distinction by requesting that their consorority's Governor not be the husband of one of the members. A second curious point about this mid-sixteenth-century group is the low incidence of traceable kinship ties between the women's and men's groups. All women are identified by a male relation, but only fourteen percent of these 
men belong to the Company of S. Maria della Pietà; of seventy-one women joining the consorority, only twelve are clearly related to a member of the confraternity. ${ }^{41}$ This was a significant drop from the percentages found in mixed confraternities of the previous century and from the strong family connections normally found in confraternities. Forty percent of women entering S. Bernardino in 1454 had been related to a male member, as were thirty percent of women joining S. Bartolomeo di Reno in 1471.42 In most contemporary Italian high-born confraternities, only female relatives of members could join the brotherhood. The women of S. Maria della Pietà suffered no such limitation; perhaps their greatest freedom lay in accepting whomever they wished, with applicants subject to an examination and vote through which the sisters separated the spiritual wheat from the blaspheming, gossiping, and dishonest chaff. ${ }^{43}$ The gap between men's and women's groups of S. Maria della Pietà is too great to be accounted for by either oblique lines of kinship or documentary lapses. It appears instead that the Bolognese patricians who had established the consorority and written its statutes were moving deliberately to broaden and reinforce obedience to the post-Bentivoglio hierarchy by casting the net of confraternal clientage over a broader social field. ${ }^{44}$

The patriciate's actions were consistent with contemporary measures to extend control over artisanal men's confraternities. They can also be seen as an effort to control women whose religious zeal might lead them either to the numerous protestant conventicles operating in Bologna, or to other independent action. It was a contemporary commonplace that women's weakness made them vulnerable to Protestant contagion, and as an international university centre, Bologna had more than its share of "luterani." Under Cardinal Giovanni Morone, Papal Governor since 1544, the city had avoided the worst of the decade's intensified prosecution of Protestantism. ${ }^{45}$ Yet this tacit toleration could not be sustained past Morone's departure in 1547. From March to September of that year, delegates to the Council of Trent had fled to Bologna in order to avoid the plague and Protestants threatening Trent. They immediately stopped the activities of two popular evangelical preachers, and stepped up investigations against local heretics. ${ }^{46}$ Over the next two years more friars and laymen were prosecuted, a local abbot was accused of distributing summaries of the Beneficio di Cristo, and eight prominent citizens were sent to the inquisitorial prison in Rome. ${ }^{47}$ Establishment of an Inquisitorial tribunal for the city alone in 1550 demonstrated both Rome's displeasure with Bologna's earlier mild approach, and its determination to 
institutionalize the new hard-line approach. ${ }^{48}$ The turning point had been 1547, and Mona Lucia's protest occurred in November of that year.

Excessive devotion and independent action was as much a concern as heresy, particularly if it threatened conventional gender roles. Elsewhere in Italy, activist Catholic laywomen like the Franciscan tertiary Angela Merici [1474-1540] had raised suspicions among clerical conservatives and reservations among lay peers. Like the beguines of northern Europe, Merici's Ursulines had initially taken private or simple vows, worn simple clothing, and lived in non-cloistered informal communities, so as to avoid the limitations of female monasticism and dedicate themselves more fully to charitable works. In 1546, Paul III put them into a separate habit and under the rule of St. Augustine. ${ }^{49}$ The Barnabites had established a similar loosely structured group for laywomen in 1535, but were pressured into enclosing it by 1557.50 In its last sessions, the Council of Trent confirmed that all female religious had to be strictly enclosed, including those women who had previously taken only simple or private vows. ${ }^{51}$ The Bolognese Senate sympathized with the conservatives on this score. It had already appealed to Rome in the early $1540 \mathrm{~s}$ for help in expanding existing nunneries, and in creating new ones to handle the increasing number of women taking vows. ${ }^{52}$ Creating new consororities was a natural extension of this concern from clerical to lay life, and the emphasis on political obedience in statutes of S. Maria della Pietà bears out the continuity. Bologna's patricians drew their power from Rome, and so could not stray far from the conservative Roman model. Since inability to control women's religious dissent or independence would have discredited the patricians in the eyes of their papal masters, there was far more at stake in the Mona Lucia Bolza episode than met the eye. ${ }^{53}$

The oligarchs' strategy of containing dissent to confirm authority was effective. The Pietà consorority grew quickly, numbering seventy-one in twenty-three months. Of these sixty-one, or eighty-six percent, remained members until death, a degree of adherence not seen since the female majority among the 1399 reformers of S. Maria della Carità. Other patrician confraternities soon followed the Pietà example. A 1549 episcopal licence allowing the Company of the SSmo. Crocifisso del Cestello to add a women's section noted that the practice was being carried out by other confraternities. ${ }^{54}$ In 1552 the Company of S. Croce followed suit, and by 1569 the high-born of Buon Gesù had also established a consorority. ${ }^{55}$ The move to sexual segregation was confirmed by the episcopal visits of the late-sixteenth century; visitors sanctioned separate women's groups, while expressly forbid- 
ding the confraternity of S. Bernardino from continuing to admit women on equal terms with men. ${ }^{56}$

Over the long term, the new consororities saw a slackening of adherents and the erosion of their 'enclosure.' Among the two or three generations following the founders of S. Maria della Pietà, only thirty-eight percent of members remained active until death. With only the titular office of prioress open to them, women did not have significantly increased opportunities for administrative or liturgical responsibility and so eventually returned to the membership pattern characteristic before the mid-Quattrocento, dropping away as fast or faster than their male counterparts. Nevertheless, greater numbers of women gathered in consororities and parish confraternities, and greater numbers of nuns entered convents; the latter made up 5.4\% of the urban population by 1570 , and $7.4 \%$ by 1631.57 These increases can be credited to the demographic and economic pressures of the later sixteenth century, which had the additional effect of easing the new consororities' devotional enclosure and re-introducing the public charitable work characteristic of the earlier era. This charitable emphasis was strongest in the new parish confraternities and consororities dominated by those of artisanal rank, but it also affected the high-born, whose take-over of laudesi ospedali had left them with greatly enlarged social responsibilities. At one end of the social scale, the artisan women of S. Maria della Carità distributed bread to widows and poor confratelli; at the other, the patrician women of S. Maria del Baraccano served as Governesses overseeing the confraternal girls' home. ${ }^{58}$ In both cases, this ostensibly public role was limited to work compatible with women's private identity as caretakers of domestic material welfare, and guardians of religious and moral values. ${ }^{59}$

Obedience and order were paramount concerns by the late 1540s. One historian has noted that, while fifteenth-century confraternities emphasized devotional community, their sixteenth-century successors emphasized obedience. ${ }^{60}$ Bolognese artisanal women of the Quattrocento, who were accustomed to public worship and charity, were disenfranchised when the men of their confraternities created new devotional communities around exclusive patriarchal religious exercises. Yet they could be accommodated under the rule of obedience that spread in the Cinquecento. This is the opportunity that Mona Lucia Bolza's demonstration opened up. The origins, composition, and statutes of the S. Maria della Pietà confraternity and consorority demonstrate a subtle but consistent distinction between family patriarchy and social hierarchy, with the emphasis in obedience on the latter rather than the former. This adds a new dimension to Joan Kelly's argument that women's segrega- 
tion into a private, domestic sphere must be seen as men's reaction to the erosion of their own political power. ${ }^{61}$ The papal reconquest of Bologna had reduced the oligarchy from real to merely deputed power, and led it to base this power at least in part on its ability to control the women of the city. Thanks to the oligarchs' preoccupation with consolidating their authority, mid-sixteenth-century artisan women regained some of the latitude for confraternal participation that they had earlier lost; yet this participation was limited to the private and domestic spheres that patrician men found familiar. A lay equivalent of strict enclosure initially limited women's prayers, praise, and service to their private homes. When the consorelle were finally let out of doors and allowed to exercise a more active charitable apostolate, it was on the terms that defined their domestic role and re-inforced the oligarchy's own expanding control over social services.

\section{University of Regina}

\section{Notes}

Note: Earlier versions of this paper were presented to the Twenty-Second International Conference on Medieval Studies (Kalamazoo: May, 1987) and the Canadian Society for Renaissance Studies (Windsor: June, 1988).

Abbreviations:

$\mathrm{ASB}=$ Archivio di Stato di Bologna

- Dem $=$ Fondo Demaniale

- Osp = Fondo Ospedale

- PIE = Fondo Pii Istituti Educativi

BBA = Biblioteca Communale dell' Archiginnasio (Bologna)

- Gozz = Fondo Gozzadini

- Osp = Fondo Ospedale

1 Compagnia di S. Maria della Pietà, ASB Dem 10/7696 \#3.

2 The women's request to gather under the mantle of Mary reflects the continuing popularity in Bologna of images of S. Maria della Misericordia. The image of Mary with outstretched arms sheltering worshippers under her cloak first appeared after the Bianchi processions of 1399 and reflected a peasant's vision of Mary diverting Christ's wrath from the world. The images frequently adorned confraternal oratories and statute books, and reveal how mixed or exclusive their institutional patrons were. Some had only robed confratelli or men under the Virgin's sheltering robes, but that of the fifteenth-century Bolognese ospedale of S. Francesco included both men and women, lay and clerical (BBA Osp 72, c3r).

3 The statutes are written in two voices, with some provisions given as dictates from an unnamed higher authority to the sisters, and others as resolutions agreed upon by the sisters themselves. The consorority of SSmo. Crocifisso del Cestello received its 1549 statutes from its male sponsors, while the women of S. Maria della Carità had no statutes at all, in spite of the men's undertaking to write a set for them. Compagnia del SSmo. 
Crocifisso del Cestello, ASB Dem 1/6378 \#10. M. Fanti, S. Maria della Carità in Bologna (Bologna: 1981), p. 71, n. 39.

4 J. Henderson, "The Flagellant Movement and Flagellant Confraternities in Central Italy, 1260 - 1400," Studies in Church History, 15 (1978), 151. N. Terpstra, "Renaissance Congregationalism: Organizing Lay Worship in Renaissance Italy," Fides et Historia, 20/3 (1988), 31-40.

5 M. Fanti, "Gli inizi del movimento dei disciplinati a Bologna e la confraternita di S. Maria della Vita," Bolletino della deputazione di storia patria per l'Umbria, 46 (1969), 185.

6 L. Scaramucci, "Considerazioni su statuti e matricole di confraternite di disciplinati," in Risultate e prospettive della ricerca sul movimento dei disciplinati (Perugia: 1972), pp. 148-149. G. Alberigo, "Contributi alla storia delle confraternite dei disciplinati e della spiritualità laicale nel secc. XV e XVI," in Il movimento dei disciplinati nel settimo centenario dal suo inizio (Spoleto: 1962), p. 193.

7 A provisional census is given in N. Terpstra, "Belief and Worship: Lay Confraternities in Renaissance Bologna" (Ph.D dissertation: University of Toronto, 1989), pp. 89-91.

8 These were: S. Bartolomeo di Reno; S. Bernardino; Buon Gesù; S. Croce; SSmo. Crocifisso del Cestello; S. Francesco; S. Maria degli Angeli del Truffailmondo; S. Maria del Baraccano; S. Maria della Carità; S. Maria dei Guarini; S. Maria della Pietà; Compagnia dei Poveri.

9 In a letter to a female correspondent, Damian noted that both men and noble women eagerly embraced the practice of flagellation as a means of purgation and satisfaction for sins. Cited in Scaramucci, "Considerazioni su statuti e matricole," p. 178 n. 65. Damian alluded to contemporary disapproval when mentioning a specific woman by carefully noting that she was the widow of an upstanding builder and was herself of some significant standing.

10 G.G. Meersseman, Ordo fraternitatis: confraternite e pietà dei laici nel mondo medioevo (Rome: 1977), p. 498. Scaramucci, "Considerazioni su statuti e matricole," p. 141. An anonymous chronicler of events in the Florentine interdict of 1377 noted that women beat themselves in the confraternal processions, but this may refer to something distinctly less dramatic than public flagellation with knotted cords. R. Trexler, The Spiritual Power: Republican Florence under Interdict (Leiden: 1974), pp. 131 n. 96, 132.

11 Meersseman, Ordo fraternitatis, pp. 500-01. Scaramucci, "Considerazione su statuti e matricole," p. 141. J.R. Banker, Death in the Community: Memorialization and Confraternities in an Italian Commune in the Late Middle Ages (Athens, Georgia: 1988), pp. 146-149.

12 None of the Sicilian flagellant confraternities followed the northern practice of admitting women to non-practising membership. S. Maria di Giosafat sponsored a private oratory, as did two other female groups annexed to it in 1405 and 1436; administering these private chapels may have been the chief function of the consorority (Meersseman, Ordo fraternitatis, p. 502).

13 James Banker argues that flagellation was reserved for males as a means of expiating the guilt arising from their participation in the "morally ambiguous" activities of commerce, politics, and justice. "Women, sheltered from the new questionable social 
practices, could not help directly in the expiation through public acts." (Banker, Death in the Community, p. 149).

14 In Italy generally, women received benefits by virtue of the principle of "one flesh," that is, as wives participating in the membership of their husbands. They had no role in statute composition or revision, no voice in chapter meetings, and no administrative duties. G. Angelozzi, Le confraternite laicali: un esperienza cristiana tra medioevo e età moderna (Brescia: 1978), p. 53. Sixteenth-century Spanish flagellant brotherhoods also enrolled small numbers of women, but allowed only men to flagellate publicly. W.A. Christian, Local Religion in Sixteenth-Century Spain (Princeton: 1981), p. 189.

15 B. Pullan, Rich and Poor in Renaissance Venice: The Social Institutions of a Catholic State to 1620, (Cambridge: 1971), p. 42.

16 Female members made sheets for the hostel, and shirts and capes for its needy inmates. S. Bartolomeo di Reno, ASB PIE 1, cap. 8.

17 The list is incomplete, with the men's list lacking the letters $\mathrm{H}, \mathrm{R}$, and $\mathrm{Z}$, and the women's list lacking T, U/V, and Z. Compagnia di S. Maria dei Guarini, ASB Dem 6/6477. Fanti estimates 1428 membership at 150 men and 140 women: M. Fanti, "La confraternita di Santa Maria dei Guarini e l'ospedale di San Giobbe in Bologna," in G. Maioli and G. Roversi (ed.), Il Credito Romagnolo fra storia, arte, e tradizione (Bologna: 1985), pp. 367-369.

18 Of the original 128 men, $116(90.6 \%)$ are noted with a ' + ' in the matriculation list; of the 120 women, $10(8.3 \%)$ are noted. Of the subsequent 499 men, $132(26.45 \%)$ are noted; of the 119 women, $17(14.28 \%)$ are noted. Compagnia di S. Maria dei Guarini, ASB Dem 6/6477.

19 R.F.E. Weissman, Ritual Brotherhood in Renaissance Florence (New York: 1980), pp. 107-162.

20 From the late fifteenth century, high-born confratelli in both Florence and Venice avoided flagellation and foot-washing as injurious to their dignity: Weissman, Ritual Brotherhood, p. 206; Pullan, Rich and Poor, p. 51.

21 Alberigo, "Storia delle confraternite dei disciplinati," p. 181. Angelozzi, Le confraternite laicali, $\mathrm{p} 62$.

22 On Albergati, P. De Töth, Il Beato Nicolò Albergati e i suoi tempi (1375-1444) (Aquapendente: 1922, 1934).

23 M. Fanti, S. Maria della Carità, pp. 32; 39; 71.

24 The late sixteenth-century company historian Alessandro Stiatici, who had joined the stretta in the 1520 's, was unaware of the prior existence of a larga company. A. Stiatici, Narratione, overo cronicha del principio e fundatione dell'Hospitale di Santo Bartolomeo di Reno... (Bologna: 1590), pp. 20-22.

25 Suppression of confraternities in northern Reformation cities similarly narrowed women's participation in civic religious, philanthropic, and administrative life, since the brotherhoods had participated in church and school administration. S.C. KarantNunn, "Continuity and Change: Some Effects of the Reformation on the Women of Zwickau," Sixteenth Century Journal, 13 (1982), 35-36. 
26 G. Zarri, "I monasteri femminili a Bologna tra il XII e il XVII secolo," Atti e memorie della deputazione di storia patria per le province di Romagna, 24 (1973), 138, 143, 159.

27 For a recent translation of her devotional work for novices, "The Seven Spiritual Arms," see J.R. Berrigan, "Saint Catherine of Bologna: Franciscan Mystic," in K.M. Wilson (ed), Women Writers of the Renaissance and Reformation (Athens, Georgia: 1987), pp. 81-95.

28 G. Zarri, "L'altra Cecilia: Elena Duglio Dall'Olio (1472-1520)" in S.B. Gajano and L. Sebastiani (ed.), Culto dei santi, istituzioni, e classi notevoli in eta pre-industriale (L'Aquila: 1984), pp. 575-613.

29 "... the growth of state-organized societies involved a largely successful attempt to shape kin relations and transfer resources from kin to class-based control." M. Clawson, "Early Modern Fraternalism and the Patriarchal Family," Feminist Studies, 6 (1982), 369.

30 Fanti, "Santa Maria dei Guarini," pp. 400-404.

31 This process and its development into the Compagnia dei Mendicanti is described in Terpstra, "Belief and Worship," pp. 293-345.

32 Weissman, Ritual Brotherhood, pp. 197-201.

33 Some children's discovery of a miracle-working leaden bas relief pietà in 1502 stimulated a popular cult which Bolognese patricians soon controlled by establishing a confraternity. Twelve laymen were deputed to draw up statutes and construct a suitable church, whose main altarpiece was painted by the Bentivoglio court painter, Francesco Francia. Giovanni II, Annibale, Marcantonio, Galeazzo, Alessandro, and Ermes Bentivoglio were all among the first members. Compagnia di S. Maria della Pietà, ASB Dem 7/7693 \#4: 1, 1a. G. Guidicini, Cose notabili della città di Bologna, III (Bologna: 1868), p. 313.

34 N.Z. Davis, "Women on Top," in Society and Culture in Early Modern France (Stanford: 1975), p. 142.

35 Frequent repetitions of the Pater and Ave made up most of the devotions, together with mental confession at bedtime and frequent attendance at Mass. Compagnia di S. Maria della Pietà, ASB Dem 10/7696 \#3, cap. 6. Sick members were visited by the Prioress, and the dead were dressed in flagellant's robes to signify their connection with the men's company before being accompanied to the sepulchre by their sisters. Ibid., cap. 8. On monthly meetings, cap. 3 .

36 For the relevant section from the 1495 statutes of the Roman Confraternity del Gonfalone, see A. Esposito, "Le 'confraternite' del Gonfalone (secoli XIV-XV)," Ricerche per la storia religiosa di Roma, 5 (1984), 130. For the 1539 statutes of SS. Sacramento di S. Maria sopra Minerva, see G. Barbiero, Le confraternite del SSmo. Sacramento prima del 1539 (Treviso: 1944), p. 283.

37 The original statutes make no mention of discipline, but a revised set issued in 1534 or 1537 includes the exercise. BBA Gozz 206 \#, cap. 9.

38 Confraternal election procedures were always contentious and frequently gave rise to charges of corruption. The women of S. Maria della Pietà elected their prioress by written ballot submitted to male scrutineers. This may have limited the electorate to 
literate members, and made male manipulation of the vote far easier. Compagnia di S. Maria della Pietà, ASB Dem 10/7696 \#3, cap. 2.

39 This is one of the few substantial changes in the 1600 revision of the women's statutes: Compagnia di S. Maria della Pietà, ASB Dem 10/7696 \#4. The Company of SSmo. Crocifisso del Cestello followed the Roman model more closely by appointing the women's Governor from the start. Compagnia di SSmo. Crocifisso del Cestello, ASB Dem 1/6378 \#10/3.

40 Compagnia di S. Maria della Pietà, ASB Dem 10/7696 \#3, Cap. 1.

41 Twelve of the seventy-one women joining from 1547 to 1550 were related to ten men of the male group. Of the ten men, six do not remain active in S. Maria della Pietà until death; the two men who have both a wife and a daughter in the women's group do remain until death. Ibid.; BBA Gozz 206 \#8.

42 The exact percentages are $38.23 \%$ of S. Bernardino women and $30.76 \%$ of S. Bartolomeo di Reno women. Reversing the question, $15.85 \%$ of S. Bernardino men and $2.03 \%$ of S. Bartolomeo men were related to female members. Compagnia di S. Bernardino, ASB Dem 8/7639 \#1. Compagnia di S. Bartolomeo di Reno, ASB PIE \#1.

43 Their sisters in the Roman Confraternity del Gonfalone had to submit all applicants to the men's company for investigation and approval. Esposito, "Le 'confraternite' del Gonfalone," p. 129.

44 A remarkably similar case of men opening their confraternity to women during a time when authority was under threat occurred in Florence in 1377 . With the city under an interdict, the only organized religious service open to the laity was through the confraternities, and the men of S. Zanobio were besieged with appeals from women seeking entry to the company and its spiritual benefits; they and many others complied with the request. Trexler, Spiritual Power, p. 131.

45 Morone was an early advocate of the spiritualist work, Il Beneficio di Cristo; among the charges in his 1557 prosecution for heresy was the claim that while Governor in Bologna he had guaranteed Protestants immunity from prosecution and allowed German Lutheran students to profess their faith publicly. G. Brown, Italy and the Reformation to 1550 (Oxford: 1933), pp. 269-273. Massimo Firpo and Dario Marcatto are currently producing a five-volume critical edition of records relating to Morone's prosecution under the title, Il processo inquisitoriale del Cardinal Giovanni Morone. Edizione critica (Rome: 1981-).

46 A. Battistella, Il S. Ufficio e la riforma religiosa a Bologna (Bologna: 1905), pp. 26-28.

47 The eight were freed after a year because of the death of Paul III (November, 1549). Battistella, Il S. Ufficio, p. 27.

48 Dominican friar Leandro Alberti headed the new tribunal. G. Brown, Italy and the Reformation to 1550 (Oxford: 1933), p. 199.

49 In 1572, Carlo Borromeo "won" them monastic status and strict enclosure. Catholic Encyclopedia I (New York: 1907), pp. 481-482. R.P. Liebowitz, "Virgins in the Service of Christ: The Dispute over an Active Apostolate for Women during the Catholic Reformation," in R. Ruether and E. McLaughlin (ed.), Women of Spirit: Female Leadership in the Jewish and Christian Traditions (New York: 1979), p. 135-138. 
50 H.O. Evennett, "The New Orders," in G.R. Elton (ed.), The New Cambridge Modern History, Vol. II: The Reformation, 1520-1559 (Cambridge: 1958), pp. 288-290.

51 The Fifth Decree on Regulars in Session XXV imposed strict enclosure on all female religious; it was reinforced by Pius V's 1566 Edict Circa Pastoralis. Liebowitz, "Virgins in the Service of Christ," p. 140.

52 Gabriella Zarri sees this as a politically-motivated appeal by an oligarchy in the process of consolidating its authority. Zarri, "Monasteri femminili," pp. 143-144.

53 The Protestant city council of Zwickau also saw independent religious expression by women as a social threat, and in 1529 used exile to break up a local evangelical women's group whose members met for preaching and prayer. Karant-Nunn, "Women of Zwickau," pp. 39-40.

54 Compagnia di SSmo. Crocifisso del Cestello, ASB Dem 20/6397 c.33 (20/10/1549).

55 Compagnia di Buon Gesù, BBA Gozz 203 \#8. Compagnia della S. Croce, ASB Dem 3/6669, ii, iii.

56 In the Episcopal Visit of 1593, the Company of S. Bernardino was expressly forbidden from continuing to include female members. ASB 8/7639 \#2.

57 The actual numbers in 1570 were 2,198 nuns in an urban population of 61,742 . G. Zarri, "Monasteri femminili," p. 144.

58 Three governesses were drawn monthly from the body of Baraccano consorelle to supervise the entry and deportment of orphaned and 'vulnerable' girls. They were assisted by three confratelli and their own chaplain: Compagnia di S. Maria del Baraccano, ASB PIE 561, c.93; ASB PIE 563, c.7. Fanti, S. Maria della Carità, p. 50; 71 n.39.

59 J.C. Brown, “A Women's Place was in the Home: Women's Work in Renaissance Tuscany," in M.W. Ferguson et al (ed), Rewriting the Renaissance: The Discourses of Sexual Difference in Early Modern Europe (Chicago: 1986), pp. 215-216. D. Willen, "Women in the Public Sphere in Early Modern England: The Case of the Urban Working Poor," Sixteenth CenturyJournal, 19 (1988), 565-573. M. Wiesner, "Women's Defense of their Public Role," in M.B. Rose (ed), Women in the Middle Ages and the Renaissance: Literary and Historical Perspectives (Syracuse: 1986), pp. 5-6.

60 Weissman, Ritual Brotherhood, p. 219.

61 J. Kelly, "Did Women Have a Renaissance?," Women, History, and Theory (Chicago: 1984), pp. 41-47. In a recent article, Diane Willen argues that women's participation in poor relief "questions or, at the least, severely qualifies the very existence of separate private/public spheres in the early modern period," but this is only on the narrowest interpretation of the spheres; her study confirms that women involved in poor relief were little more than the deputed mothers of social paternalism. Willen, "Women in the Public Sphere,” p. 559. 


\section{Appendix A}

\section{MALE AND FEMALE MEMBERSHIP IN BOLOGNESE CONFRATERNITIES}

The Table below gives the absolute numbers and relative percentages of male and female membership in fifteenth- and sixteenth-century confraternities. Statistics are taken from confraternal matriculation lists. "Original Members" are those inscribed when the list was begun, and "Added Members" are those who joined the confraternity through the life of the matriculation list.

\section{ORIGINAL MEMBERS}

\section{S. Bartolomeo di Reno}

S. Bernardino

$$
\text { [1471-ca. 1510] }
$$

[1454-ca. 1570]

S. Maria del Baraccano

$$
\text { [1518-mid XVI] }
$$

S. Maria della Carità

$$
\text { [1399-ca. 1530] }
$$

S. Maria dei Guarini

$$
\text { [1428-ca. 1530] }
$$

$\begin{array}{crl}\text { (m) } & 393 & {[93.8 \%]} \\ \text { (f) } & 26 & {[6.2 \%]} \\ \text { (m) } & 82 & {[63.08 \%]} \\ \text { (f) } & 48 & {[36.92 \%]} \\ \text { (m) } & 273 & {[89.22 \%]} \\ \text { (f) } & 33 & {[10.78 \%]} \\ \text { (m) } & 31 & {[37.35 \%]} \\ \text { (f) } & 52 & {[62.65 \%]} \\ \text { (m) } & 128 & {[51.61 \%]} \\ \text { (f) } & 120 & {[48.39 \%]}\end{array}$

ADDED MEMBERS

$\begin{aligned} 253 & {[92.67 \%] } \\ 20 & {[7.33 \%] } \\ 337 & {[43.32 \%] } \\ 441 & {[56.68 \%] } \\ 383 & {[89.9 \%] } \\ 43 & {[10.1 \%] } \\ 269 & {[63.15 \%] } \\ 167 & {[36.85 \%] } \\ 499 & {[80.74 \%] } \\ 119 & {[19.26 \%] }\end{aligned}$

SOURCES: S. Bartolomeo di Reno, ASB PIE \#1; S. Bernardino, ASB Dem 8/7639\#1; S. Maria del Baraccano, ASB Osp \#3b; S. Maria della Carità, ASB Dem 4/7673 \#1; S. Maria dei Guarini, ASB Dem 6/6477.

\section{Appendix B}

\section{MALE AND FEMALE RETENTION RATES IN BOLOGNESE CONFRATERNITIES}

The Table below gives the percentage of males and females who remained members in good standing at the time of death. Statistics are drawn from those confraternal matriculation lists that doubled as Books of the Dead. As with Appendix A, "Original Members" are those inscribed when the list was begun, and "Added Members" are those who joined the confraternity through the life of the matriculation list.

\section{S. Bartolomeo di Reno}

S. Bernardino

$$
\text { [1471-ca. 1510] }
$$

[1454-ca. 1570]

S. Maria del Baraccano

$$
\text { [1518-mid XVI] }
$$

S. Maria della Carità

$$
\text { [1399-ca. 1530] }
$$

S. Maria dei Guarini

$$
\text { [1428-ca. 1530] }
$$

\section{ORIGINAL MEMBERS}

(m) $\quad 94.66 \%$

(f) $\quad 53.85 \%$

(m) $64.63 \%$

(f) $\quad 37.50 \%$

(m) $\quad 91.20 \%$

(f) $\quad 39.40 \%$

(m) $100.00 \%$

(f) $\quad 96.00 \%$

(m) $\quad 90.60 \%$

(f) $\quad 8.30 \%$

\section{ADDED MEMBERS}

$43.08 \%$

$25.00 \%$

$64.69 \%$

$28.34 \%$

$43.34 \%$

$35.56 \%$

$89.59 \%$

$55.00 \%$

$26.45 \%$

$14.28 \%$

SOURCES: See Appendix A 